\title{
A new species of Sycorax (Diptera, Psychodidae, Sycoracinae) from the Pacific coast of Colombia
}

\author{
Eduar Elías Bejaranoํㅗ Patricia Duque² \& Iván Darío Vélez²
}

\begin{abstract}
${ }^{1}$ Grupo de Investigaciones Biomédicas, Universidad de Sucre, Cra. 14 No. 16-B-32, A.A. 406, Sincelejo, Colombia. eduarelias@yahoo.com ${ }^{2}$ Programa de Estudio y Control de Enfermedades Tropicales - PECET, Universidad de Antioquia, Calle 62 No. 52-59, A.A. 1226, Medellín, Colombia.
\end{abstract}

\begin{abstract}
A new species of Sycorax (Diptera, Psychodidae, Sycoracinae) from the Pacific coast of Colombia. Sycorax utriensis n. sp. is described and illustrated from a male specimen collected with a CDC light trap in the Parque Nacional Natural Ensenada de Utría, on the Pacific Coast of Colombia. Five species of Sycorax are now known from Colombia, S. andicola Young, 1979, S. colombiensis Young, 1979, S. fairchildi Young, 1979, S. trispinosa Young, 1979 and S. utriensis n. sp.
\end{abstract}

KEYWORDS. Biogeographic Chocó; Colombia; psychodid fly; taxonomy.

RESUMO. Uma nova espécie de Sycorax (Diptera, Psychodidae, Sycoracinae) de Costa Pacífica da Colômbia. Sycorax utriensis n. sp. é descrita e ilustrada a partir de um exemplar macho coletado com armadilha luminosa CDC no Parque Nacional Natural Ensenada de Utría, localizado na Costa do Pacífico Colombiano. São conhecidas agora cinco espécies de Sycorax da Colombia, S. andicola Young, 1979, S. colombiensis Young, 1979, S. fairchildi Young, 1979, S. trispinosa Young, 1979 e S. utriensis n. sp.

PALAVRAS-CHAVE. Chocó Biogeográfico; Colômbia; psicodídeo; taxonomia.

The subfamilies Phlebotominae Rondani, 1840 and Sycoracinae Jung, 1954 have received most attention among members of the family Psychodidae Newman, 1834 since they include bloodsucking species that may be vectors of pathogenic agents (Young 1979). Although phlebotomine sand flies are abundant in collections of Neotropical psychodids, Sycoracinae are very rarely represented. This subfamily is considered by some taxonomists to be an ancient group, with relatively few species still extant (Duckhouse 1972). To date only 35 species have been described worldwide (Jezek 1999; Bravo 2003, 2007), including three fossil species from Baltic and French amber (Meunier 1905; Azar et al. 2007). Additionally, three indeterminate fossil taxa of Sycoracinae also have been reported (Saigusa 1974; Quate \& Vockeroth 1981; Azar et al. 2007). This is far fewer than the 900 known species of Phlebotominae, almost 500 of which occur in the Americas (Galati 2003).

Four of the nine species of Sycorax Curtis, 1839 known from the Neotropics are endemic to Colombia, i.e., S. andicola Young, 1979, S. colombiensis Young, 1979, S. fairchildi Young, 1979 and S. trispinosa Young, 1979 (Tonnoir 1929; Barretto 1956; Young 1979; Bravo 2003, 2007). During a revision of the psychodids deposited in the Colección de Vectores y Hospedadores Intermediarios de Enfermedades Tropicales (VHET) of the Programa de Estudio y Control de Enfermedades Tropical (PECET), a specimen labelled as Sycorax sp. was discovered. This was the only representative of the genus among 5365 phlebotomines collected during a two-year entomological study of leishmaniasis in the Pacific Coast of Colombia (Duque et al. 2004). Examination of this specimen revealed it to be a new species which is described and illustrated here, raising the total number of psychodid species recorded from Colombia to 184 (Bejarano 2006; Bejarano et al. 2006).

\section{MATERIALS AND METHODS}

The type material was collected with a CDC light trap installed $15 \mathrm{~m}$ above ground in the crown of a tree in the Parque Nacional Natural Ensenada de Utría ( $\left(06^{\circ} 01^{\prime}\right.$ N, $77^{\circ} 20^{\prime}$ W), a national park located south of the Municipality of Bahía Solano, in the Colombian department of Chocó. This park lies on the Pacific coast of Colombia, a region considered to be one of the most biodiverse in the world (García-Kirkbride 1986). The area is classified as lying within a very humid tropical forest life zone (Holdridge 1967). The mean annual temperature of the region reaches $28^{\circ} \mathrm{C}$ and relative humidity is $80-95 \%$. Annual rainfall on the Pacific Coast of Colombia is approximately $10000 \mathrm{~mm}$.

The specimen was cleared in lactophenol and mounted in Canada balsam. Morphometric measurements were made with an eyepiece micrometer using a Nikon YS2-T microscope. The holotype is deposited in VHET/PECET at the Universidad de Antioquia in Medellín, Colombia. The morphological terminology used herein follows in part those of Young (1979) and McAlpine (1981). 
RESULTS

\section{Sycorax utriensis $\mathbf{n} . \mathbf{s p .}$}

(Figs. 1-7)

Type locality. Parque Nacional Natural Ensenada de Utría, Bahía Solano, Chocó, Colombia.

Description (all measurements in micrometres). Mediumsized psychodid, length from tip of labro-epipharynx to end of genital terminalia 2617.

Head. Brown, with palps and first antennal segments somewhat paler. Head covered with large hair scars interspersed with smaller scars. Vertex without midline. Head 595 wide, height from vertex to distal margin of clypeus 509. Clypeus wider than long, not extending further than level of eyes and bearing 10 setae. Width of clypeus 98, length 43. Length of labroepipharynx 94. Labial sutures forming groove. Eyes compound without ocular bridge, height 360. Interocular distance 116, equivalent to diameter of 5.18 ommatidia. Scape and pedicel sub-spherical, length of internal border of the scape 77 and width 84. Pedicel somewhat smaller than scape, length 66 and width 74. Scape and pedicel with some hair scars, scape also bearing four small sensorial setae near base. Flagellomere I incomplete, with several scars and simple bristles. Other flagellomeres lost. Maxillary palps with four segments, shorter than head. Palpomere lengths: first 32, second 39, third 52, fourth 81 , in proportion 1.0-1.22-1.62-2.53. Palpal formula 1.2.3.4. First palpomere with $\sim$ about 6 sensilla distributed on distal two-thirds of internal side of segment. Second palpomere with $\sim 10$ sensilla covering almost all internal surface of segment. Third palpomere with four spiniform bristles. Fourth palpomere with 4-5 spiniform bristles, two of these located on segment apex.

Thorax. Mesonotum brown, pleurae paler. Halteres strongly pigmented. Wings with rounded apex. Length of wing from base of costal vein 1813, maximum width 787 . Ratio between wing length and maximum width 2.3. Length of principal wing veins: $R_{1} 840, R_{2}+R_{3} 509, R_{4} 586, R_{5} 1004, M_{1} 672, M_{2} 581, M_{3}$ 912, $\mathrm{M}_{4}$ 595. Humeral vein absent. Vein Sc almost straight, ending indistinctly in $\mathrm{R}_{1}$. Basal radial cell open at distal extremity. Vein $\mathrm{R}_{5}$ discontinuous at base. Radial and medial furcae separated by 73 . Veins $R_{4}, R_{5}, M_{1}$ and $M_{2}$ not clearly touching apex of wing. Transverse vein $r-m$ absent. $\mathrm{CuA}$ vein almost reaching wing margin. Transversal vein $\mathrm{m}$-cu present. Veins $\mathrm{R}_{1}$ and $\mathrm{CuA}$ thickened and sclerotized. Halteres covered with numerous large hair scars. Length of haltere 96, maximum width 49. Ratio between length and maximum width of halter 2.37. Legs lost.

Abdomen. Pale brown, with hair scars on sternites and tergites. Length 1324, including terminalia. Cercus long and rounded, exceeding length of gonostyle. Apex of cercus covered with abundant setae, with length 79 and width 47 . Gonocoxite suboval in lateral view. Gonostyle complex, subquadrate-shaped in lateral view. This bears small sensorial setae implanted close to the articulation with gonocoxite and multiple thick spines distributed throughout structure. Right gonostyle with total of 15 spines, left with 17 . Three long spines overlap one of the extremities of the gonostyle. Opposite extremity with spine implanted on digitiform projection, base of which has row of 3-4 spiniform bristles. Each gonostyle also bearing five long spiniform hairs arranged in a longitudinal row. The parameres are not discernible. Genital pump short, dilated at base and apex in dorso-ventral view. Length of genital pump 87, basal width 41 and apical width 24 . Aedeagus longer than genital pump, apparently terminating in a single point. Aedeagus length 114, maximum width 47. Aedeagus also with pair of lateral projections near to apex, coming to a point distally and giving structure a conical appearance. Junction of genital pump with aedeagus showing rectangular sclerite in dorsoventral view, with length 19 and width 28 .

Type Material. Holotype: 1 male, Parque Nacional Natural Ensenada de Utría, Bahía Solano, Chocó, Colombia, 1-XI-93, CDC light trap, P. Duque coll., VHET (PPCO-2496).

Bionomics. The discovery of $S$. utriensis n. sp. approximately $15 \mathrm{~m}$ above the ground in the crowns of trees is completely unprecedented among Neotropical members of this genus. Most Sycoracinae described to date have been collected a few metres above ground, generally in vegetation close to running water.

Distribution. Colombia, Chocó. Known only from type locality.

Etymology. The name of the new species derives from the Bay of Utría, a national park of extraordinary biodiversity in which the type specimen was collected. In Utría it rains 300 days per year and the Pacific Ocean is adjacent to the forest. According to the Amerindian natives of the region, Utría was a beautiful Indian girl who one day disobeyed her mother's orders by bathing in the sea before becoming a woman. As punishment for her disobedience was changed into a whale. Since then, she returns ever year from July to September to visit her people as one of the yubarta whales who flee from the cold of the Antarctic in search of the warm waters of the bay to give birth to her calves.

\section{TAXONOMIC DISCUSSION}

S. utriensis n. sp. can be separated easily from the four known Colombian Sycorax, by its conspicuously longer fourth palpomere, 2.5 times the length of the first. This gives a palpal formula of 1.2.3.4 in S. utriensis n. sp., while in S. andicola and S. trispinosa the formula is 4.3.1.2, in S. colombiensis it is 4.3.2.1 and in S. fairchildi it is 4.(3.1).2. It is important to emphasize that in the last four species, fourth palpomere is always the shortest palpal segment.

In addition, there are several morphological differences in the genitalia between $S$. utriensis $\mathbf{n}$. sp. and the other Sycorax species above mentioned. $S$. andicola is distinguished by the greater length of the aedeagus and genital pump, 165 and 200, respectively. $S$. colombiensis and $S$. fairchildi are characterized by the slender aedeagus, which in dorsal view, is subequal in 

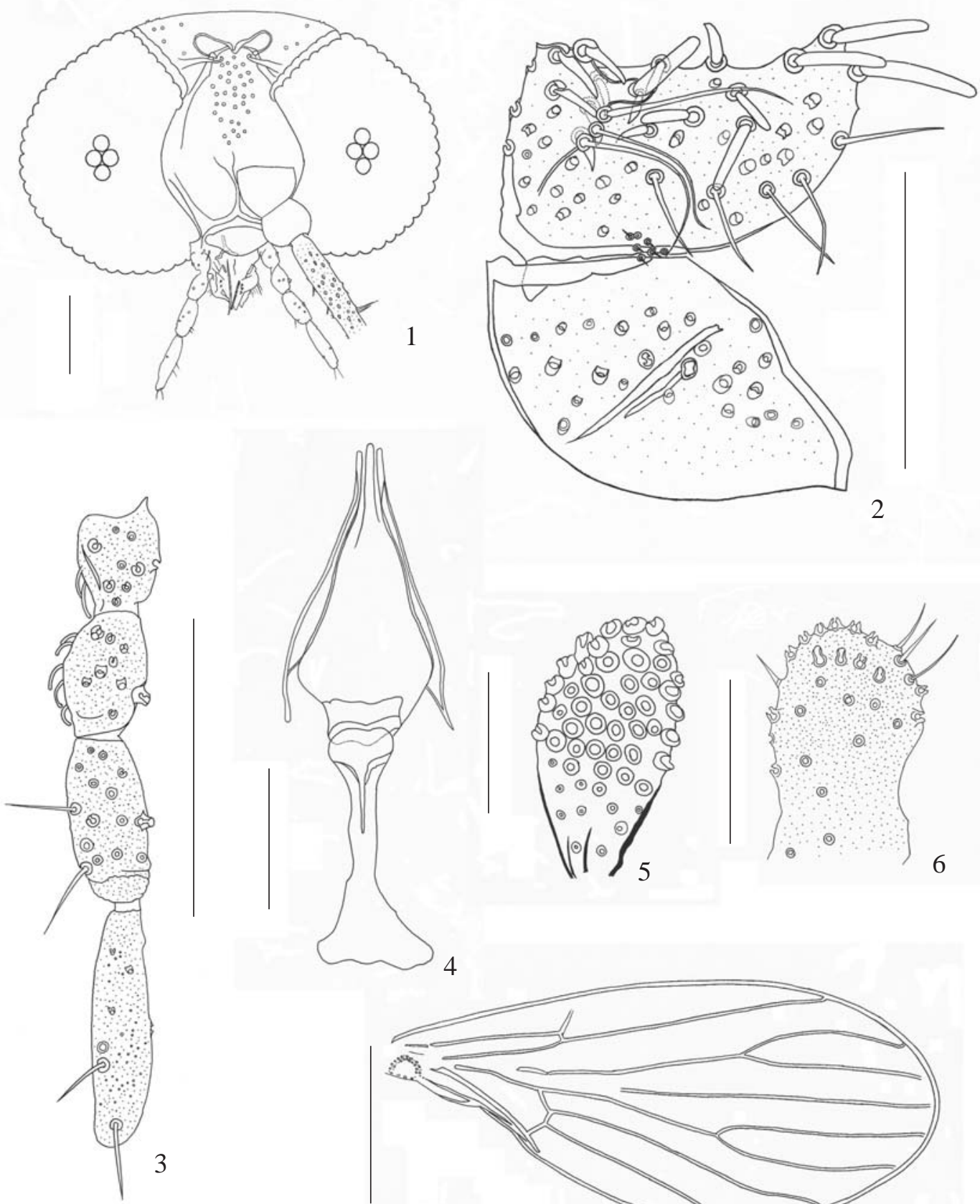

3

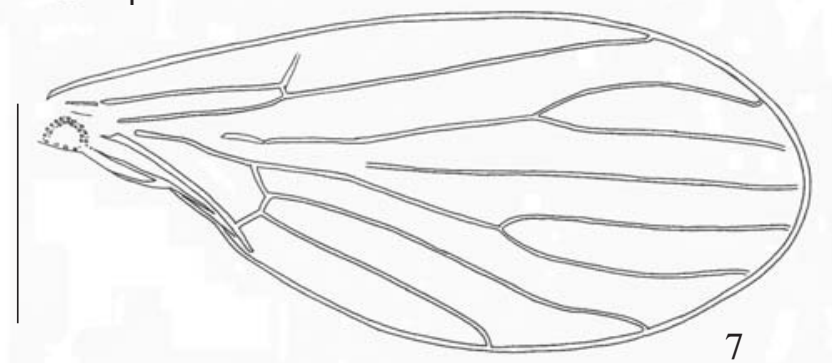

Figs. 1-7. Sycorax utriaensis $\mathbf{n}$. sp., holotype male: 1 , head, scale bar $=100 \mu \mathrm{m} ; 2$, gonocoxite and gonostyle, lateral view, scale bar $=100 \mu \mathrm{m}$; 3 , maxillary palp, scale bar $=100 \mu \mathrm{m} ; 4$, genital pump and aedeagus, dorso-ventral view, scale bar $=50 \mu \mathrm{m} ; 5$, halter, scale bar $=50 \mu \mathrm{m} ; 6$, cercus, dorso-ventral view, scale bar $=50 \mu \mathrm{m} ; 7$, wing, scale bar $=500 \mu \mathrm{m}$.

width. S. trispinosa have a genital pump subequal in width in dorsal view and faintly broad at base.

S. utriensis n. sp. also can be distinguished from $S$. andicola, S. colombiensis, S. fairchildi and S. trispinosa by the morphology of the cerci. These are rounded in the new species, pointed in $S$. andicola, $S$. colombiensis and $S$. trispinosa, and apically semi-pointed in S. fairchildi. The presence of multiple stout spines on the gonostyle of the new species allows it to be differentiated from $S$. assimilis Barretto, 1956, S. bahiensis Bravo, 2003 and S. longispinosa Bravo, 2007, which lack these structures. The new species lacks the elongated genital filaments characteristic of $S$. chilensis Tonnoir, 1929.

Among the Neotropical Sycorax, S. utriensis n. sp. partly resembles S. satchelli Barretto, 1956 from Brazil. However, the new species can be distinguished from the latter principally 
by the number of spines on the gonostyle and by the location of the radial and medial furcae of the wing. S. utriensis $\mathbf{n} . \mathbf{s p}$. has $15-17$ spines on the gonostyle, while $S$. satchelli has only eight. On the wing of $S$. utriensis $\mathbf{n}$. sp. the furcae radial and medial are separated by 73 , close to the middle of vein $\mathrm{R}_{5}$, and the medial bifurcation lies at the same level as the insertion of vein $\mathrm{M}_{4}$. In $S$. satchelli the radial and medial furcae are located at the same level, relatively close to the base of vein $R_{5}$ and the medial bifurcation is at a different level from the $\mathrm{M}_{4}$ insertion.

According to Duckhouse (1972), S. utriensis n. sp. should belong to the genus Parasycorax Duckhouse, 1972, based on the characteristics of multiple spines on the gonostyle, an elongated fourth palpomere, open radial basal cell and relative proximity of the radial and medial furcae of the wing. However, until new taxonomic tools are used to study the phylogenetic relationships of the Sycoracinae, we follow Jezek (1999) in placing all members of this subfamily within a single genus.

Acknowledgements. To Alveiro Pérez-Doria for help with the drawing of the figures, and anonymous reviewers for their valuable comments and suggestions. This study received financial support from Colciencias (project no. 1115-04-018-92), the Instituto Francés de Estudio Andinos (IFEA) and the Universidad de Antioquia.

\section{REFERENCES}

Azar, D.; A. Tahchy \& V. Perrichot. 2007. The oldest Sycoracinae (Diptera: Psychodidae) from the French Cretaceous amber. Alavesia 1: 5-10.

Barretto, M. P. 1956. Sobre o gênero Sycorax Hal., com as descrições de duas novas espécies do Brasil (Diptera, Psychodidae). Folia Clinica et Biologica 26: 71-78.

Bejarano, E. E. 2006. Lista actualizada de los psicódidos (Diptera: Psychodidae) de Colombia. Folia Entomológica Mexicana 45: 47-56.

Bejarano, E. E.; P. Duque \& I. D. Vélez. 2006. Redescripción de la hembra de Lutzomyia vattierae (Diptera: Psychodidae, Phlebotominae) de la serranía de La Macarena, Colombia. Biomédica 26: 556-561.

Bravo, F. 2003. Descrição de Sycorax bahiensis sp. nov. (Diptera,
Psychodidae) do Brasil. Revista Brasileira de Zoologia 20: 385387.

Bravo, F. 2007. First record and description of a new species of Sycorax Curtis (Diptera: Psychodidae, Sycoracinae) from the Brazilian Amazon. Neotropical Entomology 36: 525-528.

Duckhouse, D. A. 1972. Psychodidae (Diptera, Nematocera) of South Chile, subfamilies Sycoracinae and Trichomyiinae. Transactions of the Royal Entomological Society of London 124: 231-268.

Duque, P.; I. D. Vélez; M. Morales \& D. Sierra. 2004. Sand flies fauna involved in the transmission of cutaneous leishmaniasis in AfroColombian and Ameridian communities of Chocó, Pacific Cost of Colombia. Neotropical Entomology 33: 255-264.

Galati, E. A. B. 2003. Classificação de Phlebotominae, p. 23-51. In: E. F. Rangel \& R. Lainson (eds). Flebotomíneos do Brasil. Rio de Janeiro, Fiocruz, 368 p.

García-Kirkbride, C. 1986. Biological evaluation of the Chocó Biogeographic Region in Colombia. Washington, World Wild Fund, $61 \mathrm{p}$.

Holdridge, L. R. 1967. Life zone ecology. San José, Costa Rica, Tropical Science Center, 206 pp.

Jezek, J. 1999. Comments on the correct grammatic gender of Sycorax Curt. and Philosepedon Eat. (Diptera: Psychodidae) with world catalogue. Dipterologica bohemoslovaca 9: 83-87.

McAlpine, J. F. 1981. Morphology and terminology - Adults, p. 9-63. In: J. F. McAlpine; B. V. Peterson; G. E. Shewell; H. J. Teskey; J. R. Vockeroth \& D. M. Wood (eds.). Manual of Nearctic Diptera. Ottawa, Research Branch, Agriculture Canada, Monograph 27, volume 1, vi+674 p.

Meunier, F. 1905. Monographie des Psychodidae de l'ambre de la Baltique. Annales Historico-Naturales Musei Nationalis Hungarici 3: 235-255.

Quate, L. W. \& J. R. Vockeroth 1981. Psychodi-dae, p. 293-300. In: J. F. McAlpine; B. V. Peterson; G. E. Shewell; H. J. Teskey; J. R. Vockeroth \& D. M. Wood (eds.). Manual of Nearctic Diptera. Ottawa, Research Branch, Agriculture Canada, Monograph 27, volume 1 , vi+674 p.

Saigusa, T. 1974. Mizunami amber and fossil insects. Preliminary work on the fossil Diptera in Mizunami amber. Bulletin of the Mizunami Fossil Museum 1: 421-439.

Tonnoir, A. L. 1929. Psychodidae, Diptera of Patagonia and South Chile. Part II, Fascicle I. London, British Museum Natural History, $32 \mathrm{p}$.

Young, D. G. 1979. A review of the bloodsucking psychodid flies of Colombia (Diptera: Phlebotominae and Sycoracinae). Technical Bulletin 806. Gainesville, FL, Institute of Food and Agricultural Sciences, Agricultural Experiment Stations, 266 p. 